\title{
Islamic Perspectives on Sustainable Development
}

Farooq Ahmad Bakloo ${ }^{1}$, Asma ${ }^{2}$

${ }^{1}$ Research Scholar Kumaun University, Department of Political Science S.S.J Campus, Almora Uttarakhand.

${ }^{2}$ UGC S.R.F- Scholar Kumaun University, Department of Education S.S.J Campus Almora, Uttarakhand.

Email: farooqmajeed19@gmail.com

\begin{abstract}
In present networking society, the concept of sustainable development is the popular concept of every discipline in academic as well as the non-academic world. Sustainable development is not the game of one player, but it needs a collaborative approach to achieve the set goals. The modern uneven and anti-environment developments are showing murky results in the appearance of disasters, scarcity of drinking water and climate change. The state actors and the international community are in the race that how to reach the sustainable development goals for this they have adopted a variety of methods and, approaches. However, the fruits of these steps to attain these goals are not so notable at grass root level, particularly in the third world countries. However, there are different perspectives on sustainable development like social, economic, and environmental. However, the focal point of the present article will be on sustainable development in the framework of Islamic teachings.
\end{abstract}

Keywords: Islamic society, Islamic legislation, sustainable development, Development and sustainable development goals.

\section{Introduction}

Today in this digital age of Science and advancement of technology, the environmental degradation is the main concern of every nation's domestic policy. Every country in the world is in the velocity to unearth the tangible solution to this universal problem. The U.N. has taken the bunch of efforts to find the answer to this perilous worldwide dilemma, but no fruitful results are seen at the grassroots. The valid root behind the environmental destruction is the hubris of hedonistic consumer passion of the modern man on nature. For the fulfilment of greed desires, the contemporary man on the label of development has made gigantic of destruction to this green planet. The pace of destruction has reached its climax and now in reply nature shows a reaction in the several forms of climate change, water scarcity and other resources crises. To tackle the reactions several 
approaches have been used to mitigate the detrimental risk among these the Sustainable developments is one of the criteria which are used to conserve the green planet. It was the Stockholm conference 1972 where the conflicts between environment and the development were first addressed. The sustainable development as a concept was begotten from the report of common future by world commission on the environment and development in 1987. It was this Bundled commission that shed light on the deep insights of sustainable development as a concept as 'it is the development that meets the needs of the present without compromising the ability of future generation to meet their own needs' after that the sustainable development became the popular concept for each discipline in the academic as well as non-academic world. Thus many strategies have been applied that how to practice this sustainable development at the ground level. Thus, it was 2002 world summit on sustainable development marked a further expansion of the standard definition with widely used three branches of sustainable development economic, social, and environment. In our opinion, these three branches are vital organs of the body of sustainability development. For the proper function and implementation, it needs collective effort by different nations of the world for expected outcome results. Therefore, it was the Johannesburg declaration, which created a joint reasonability of every nation to strengthen the pillars of economic, social, and environmental for achieving the target of sustainable development at the grassroots level in the world. To attain the target recently U.N has listed 17 sustainable development goals as enumerated below:-

- End poverty in its all forms

- End hunger, achieve food security and improved nutrition, and promote sustainable agriculture.

- Ensure healthy lives and promote well being for at all ages.

- Ensure inclusive and equitable quality education and promote lifelong learning opportunities.

- Achieve gender equality and empower all women and girls.

- Ensure availability and sustainable management of water and sanitation for all.

- Ensure access to affordable reliable sustainable modern energy to all.

- Promote sustained, inclusive and sustainable economic growth, full and productive employment and decent work for all. 
- Build resilient infrastructure, promote inclusive and sustainable industrialization and foster innovation.

- Reduce inequality in among countries.

- Make cities and human settlements inclusive safe resilient and sustainable.

- Ensure sustainable consumption and production patterns.

- Take urgent action to combat climatic change and its impact.

- Conserve and sustainable use of oceans seas and marine resources for sustainable development.

- Protect restore and promote sustainable use of terrestrial ecosystems sustainably manage forests combat desertification, and halt and reverse land degradation and halt biodiversity loss.

- Promote peaceful and inclusive societies for sustainable development, provide access to justice for all, and build effective accountable and inclusive institutions at all levels.

- Strengthen the means of implementation and revitalize the global partnership for sustainable development.

Key for the sustainable development is as follows;

- Good governance.

- Equity.

- Involvement of people.

- Alertness among the public regarding the significance of sustainable development.

- Accurate execution of anti-pollution policies.

\section{Sustainable development and Islam}

Now we are approaching the nucleus of the article that sustainable development in perspective of Islam. In the Noble Quran, the Allah says, "Verily we have created all the things in proportion and measure" (Al-Quran54:49). Islam permits the consumption of environment, but this should not be arbitrary. Wastefulness and extravagance are strictly prohibited in Islam in the connection the Quran says that "o children of Adam wear your beautiful apparel at every time and place of prayer eat and drink but waste not by excess for Allah loves not the wasters" (Noble-Quran 7:31). The Muslims knows that nothing belongs to them since all belongs to mighty God, that they do not occupy earth to gain mastery over it in the biblical sense but use it responsibly in the sense of usufructs (Hofmman,1999). The 
religion Islam attaches the supreme importance to the maintenance of environment as a whole created by the God (Ibrahim ozdemir, 2002). The consumption of all natural resources is considered the right and the joint property of the entire humanity. Since Man is khalif ut Ullah on earth, so he should take every step to ensure the interests and rights of others (Iyad abumoghli).In Islam, the wastage of any natural resource or humanmade resource is probated in this regard the Message of Noble Quran is crystal clear as Allah says eat and drink but waste not by the excess ( $\mathrm{Al}$ Araf 7:31).

"Eat and drink from the provision of Allah, and do not commit abuse on the earth spreading corruption" (Noble-Quran 2:60).

And do not follow the bidding of excessive, who cause corruption in the earth and do not work good (Ash-Shu"ara' 26:151:152). And do not commit abuse on earth spreading corruption (Noble Quran 2:60).

"Allah has sent down rain from the sky and given life thereby to the earth after its lifelessness. Indeed in that is a sign for the people who listen"

(Noble Quran 16:65).

The Prophet Muhammad (PBUH) was born 570 AD in the Quraysh tribe in Mecca. George Bernard writes about the Prophet (PBUH), "He must be the savior of humanity. I believe that if a man like Muhammad were to assume the dictatorship of the modern world, he would succeed in solving its all the problems in a way that would bring it much peace and happiness" (George Bernard Shaw, 1936).

\section{Women Empowerment}

The empowerment of women is one the goal of sustainable development. Today a significant number of women and children's are the victims of conflict and poverty. The women were under fire everywhere they were raped and killed. The Same situation was during the pre-Islamic period in Arab the position of women in the Arabian society was miserable. They kill their daughters, and this practice was frequent among these people. However, when the Prophet Muhammad (PBUH) came and raised the voice against these shocking acts the tradition was erased slowly from the society. It was the Islam, in that age of darkness and ignorance, which provide the security, and respect of women and assigns her rights in the society. There are so many narrations of Prophet (PBUH) about the betterment of women. Islam prohibits murder of Women even during the wartime. The Noble Quran says that men are the protectors of women and has assigned her 1/3 share in the property which parents leave. The sayings of Prophet $(\mathrm{PBUH})$ regarding the rights and status of women as No 
marriage is valid against the consent of girl; education is essential for both Muslim men and women. Lucky is the women whose first child is the daughter. The best Muslim man is who the best is for his wife and children. The last Homily of Prophet (PBUH) in which ten thousand Muslims have participated. In that last sermon, the Prophet (PBUH) focused on the respect and rights of women.

The empowerment of women is already discussed in the Islamic teachings. However, the current hour demands to put into these teachings into practice. This will be helpful to reach the target of sustainable development in the world. This was the first cornerstone concerning empowerment of women rights in that tribal society. The second milestone of Islam was the Unity when Prophet Muhammad (PBUH) united the broken tribal society of Arabs under one flag of Islam.

\section{Social Teachings}

In this teaching, Islam especially concentrates that how a Muslims should behave with each other or other communities. The sayings of Prophet (PBUH) about the rights of a neighbour in the Islamic culture, as Prophet Muhammad (PBUH) said that he is not a believer whose neighbour is not safe from his annoyance (Shahi Bukhari). The above Hadith of the Prophet (PBUH) mentions the word neighbour and this is for all Muslim or Non-Muslim. Abdullah ibn $\mathrm{Abas}^{\mathrm{RA}}$ reported that the Prophet (PBUH) said that the believer is not he who eats full while his neighbour is hungry.

In another saying prophet Muhammad (PBUH) said that pay the worker for his work before his sweat dries ( Sunan Ibn Majah). Prophet (PBUH) said that whoever hurts a nonMuslim will not smell a whiff of paradise. It is manifest from the Teachings of Islam that it supports the notion which will be helpful for developing the sustainable society based on equality, justice and promote welfare among the people.

\section{Islam and Animal Rights}

The prophet Muhammad (PBUH) taught that Muslims should act kindly not only with human beings but also to all living beings. "Act kindly to those so that those in the heavens will be merciful to you" (Tirmidhi). Another saying Prophet Saw said women sent to hell because she tied up her cat and neither gave it food nor allowed it to free to hunt the cockroaches ( Bukhari, MUSLIM \& Musnad).

Anyone who kills a sparrow without good rationale will be called to account by Allah at the Day of Judgment (Abu Dawood). The prophet (PBUH) also commanded the Muslims that the nests of the birds should not be disturbed. One-day prophet told the tale of a traveller 
who was from the (Bani Israel). The traveler felt a lot of thirsty, so he went here and there in search of water thus he saw the well. The water level was very down in the well. Therefore, he went into the well and drank the water. After drinking water and came out of the well he saw the dog licking the damp soil with its thirsty. Saying himself the dog is thirsty like I was so he went back to the well and filled his shoes with water. Then holding it, firms returned and kept it for the dog to drink. Allah praised that servant of his act and forgave his all sins the companions then asked the prophet, so we are rewarded for watering animals the prophet replied there is a reward for giving any living creature to drink (Bukhari).

Today in the world animal rights is one of the issues, which are raised by different organizations, especially in the developed countries. Islam has already paid attention to the empowerment of animal rights, which is the core issue in the ecological point of view. Therefore, it is patent from the teachings of Islam that it fully supports the preservation of biodiversity that is also one of the sustainable development goals of 2016 enacted by the UN.

\section{Islam and Sanitation}

In modern time, sanitation is one of the severe problems in the third world countries. Due to the shortage of sanitation bunch of diseases are born which have consumed a massive number of lives in the world. These countries have formulated various programs to get rid of this problem. Our country has also launched an extensive and famous program called Swacha Bharat Mission. And, if we study sanitation in the context of Islam, we found that the religion Islam is deep focused on the sanitation as there are special provisions for purity like how to bathe? How to make ablution? Found in the Quran and Sunnah. To cite the example of Praying as before Salaha the person has to do ablution that is the essential for praying without Allah will not accept this praying. In this context, there are myriad narrations, which are emphasizing the need for sanitation in Islam. It is apparent from the biography of the Prophet (PBHU)that though out his life the paid vast attention to the cleanness in this regard Quran also commands that "Allah loves those who turn to him constantly and he loves those who keep themselves clean" (Noble-Quran 2:22). The Prophet (PBUH) said that cleanness is the half of faith (Muslim). Prophet (PBUH) said about street cleanups, removing harmful things from the road is an act of charity (narrated by the Abu Dharr Al-Ghafari).

Sanitation for all is one of the selected sustainable development goals of 2016. Islam has already addressed this subject not only discussed but also made it mandatory for the Muslims. Hence, from the above teachings, it is crystal clear that Islam is the religion that supports the sustainable development. 


\section{Islam and Plantation}

The Prophet (PBHU) said that planting a tree is the continuous charity (Muslim). In another Hadith the prophet commanded his followers that 'if you have sapling if you have time be certain to plant it even if doomsday starts to break forth" (Al- Munawi Fayd alQadir).if the Muslim plants a tree or sow seeds and then a bird or a person or an animal eats from it, it is regarded as a charitable gift for him" (Bukhari). Even during the fight, Prophet (PBUH) has issued war ethical code and instructions to the Soldiers as:

Do not kill a women, do not cut a tree, do not kill an infant, do not kill a child, do not kill the sick, do not kill an old man, don't betray, do not kill priest, don't destroy worship places, never mutilate bodies, don't kill an animal except to eat, don't destroy buildings, always keep a promise, be kind to the prisoners, don't force to anyone to Islam and forgive and release captives (Bukhari).

Today plantation is one of the tools, which are used for the mitigation of global warming, and climate change, which is considered the biggest threat to the human development on this green planet. On an average 83000 people died and 211 million were affected each year by the natural disasters from 2000 to 2013(sustainable development goals report 2016). Each country has set a target to increase the forest cover to counter the climate change and to improve the forest sustainability. In current time the threat to the forest sustainability is the anthropogenic activities. However, in Islam, immense attention has been paid to the forestation, and it is not allowed even during the war times that a Muslim destroys the forests or cut the trees. In this way, the teachings of Islam have already commanded the followers to maintain the forest sustainability through the plantation.

\section{Financial Teachings}

In this teaching, the Islam emphasizes the ways of earning which are mentioned in the Noble Quran and the teachings of Holy Prophet (PBUH). The instructions concentrate on the probation of interest. The source of finance in the Islamic society is the Zakat, which every Muslim has to pay (2.5\%) if he eligible for paying according to the rules of Islam this Zakat, is used for the welfare and betterment of the poor people, which is the right of poor. In Islam, there is a particular department for this called as Baytul Mall? Abu Bakhar ${ }^{\text {RA }}$, the first caliph of Islam, announced war against those Muslims who did not pay the Zakat during his time. Paying Zakat is obligatory for the Muslim who is eligible for this. There are some studies, which prove that the Sharia banking approach is the suitable to tackle the economic disparities in the world. 
For eradication of poverty, the Quran says that "and you don't encourage one another to feed the poor" (Noble-Quran 89:18).

In the contemporary period, poverty is the grave issue in the world. To curb economic inequality in Islam Quran has recommended the system of Zakat operated by the particular department called Baitul - Mall. The Zakat paying is essential after praying. It is one among the crucial five pillars of Islam. The Noble Quran has given large focus on Zakat and its importance, which is for the needy and poor people and used for the welfare of the public. If we study, the Islam in Spain Muslims rulers paid their attention to the protection of the people by constructing the hospitals, open schools, and provides the basic ammonites of life to the people. The Muslim rulers have developed the Spain, which earlier was destroyed by the papacy (an Islamic history BBC 4).

\section{Teachings Regarding the Ruling}

In these teachings of Islam, emphasize what the rights and duties of a Muslim Ruler are. If anyone (whether he is Islamic ruler or common subject) killed a person, not in retaliation of Murder or to spread mischief in the land, it would be as he has killed whole humanity (Noble Quran 5:35). In this context of the ruling, there are a lot of sayings, but I want to quote one of his Hadith of Prophet SAW the ruler is responsible for his subjects, and he will be questioned on the day of judgment (Musnad Ahmad). In Islam, the ruler should focus on the welfare of the people. The Islamic ruler should be the keen supporter of justice and promote the peace in the region. We found many examples in Islamic literature during the time of first four great rulers of Islam of Abu Baker ${ }^{\text {RA, }}$, Farooq ${ }^{\text {RA }}$ Usmann ${ }^{\text {RA, }}$ and Ali ${ }^{\text {RA }}$ being the rulers they live their lives like an ordinary person very in a simple manner.

Good Governance plays a prime role in the way of sustainable development, and if Govt. is corrupt, then nothing can be done for the welfare of the society. The teaching of Islam strictly prohibits the fraud and dishonesty on any level. The prophet SAW said the man who deceives us is not among us (Muslim). The ruling system of Islam based on the following pillars as highlighted below:-

- Fear of Allah (Tawhid)

- Universal Justice.

- Gender Justice.

- Accountability.

- The welfare of the people.

- Focus on the poor. 
- Protection of minorities.

- Protection of fundamental rights of citizens.

- Giving the protection of religious places of non-Muslims.

- The promoter of the peace and Universal Brotherhood.

- Against the racism and any form of Caste.

It is evident from above that the Islamic ruling teachings which are intensely focused on the primary goals of the sustainable development. I think we should study the Noble Quran and the Teachings irrespective of religion and should develop a robust approach, which will be helpful in achieving the sustainable development goals.

\section{Conclusion}

As we understand, the notion of sustainable development is nowadays are using to mitigate multiple environmental degradations. However, most people are not cognizant of this strategy very well. Besides this, most of the Muslim countries are coming in the cycles of water shortage so these countries should use the Islamic model of sustainable development to preserve their further water resources and should launch a campaign to spread these green teachings of Islam. Islam is called the code of life or way of life, so there is a solution to every problem. However, scholars of Islam should appropriately use these teachings. The preachers of Islam should reflect through out of box strategy and should instruct the common adherents of Islam that how to use these green teaching of Islam to mitigate the various current forms of crises which we are witnessing in contemporary times. The educational institutions in the Islamic countries should allow the small projects to the students through which they can be aware the common masses about the importance of the sustainable development along with the Islamic teachings that are focusing on this notion.

In the above study, an effort was made to analyze the central Goals of sustainable development drafted by the UN in the context of Islam. In the study, it was found that Islam has already explored these concerns not only examined but also dispenses the medians of how to produce a good society in the modern world a sustainable society. Islam is the religion, which discusses all the ingredients of life in a better way and also addresses these environmental concerns through efficient means in the teachings. If Islam is implemented in letter and spirit, way at an individual and collective level through the process of peace will lead to development. And will address all the issues which the human beings are faced today. 
Pakistan Journal of Humanities and Social Sciences, 6(4), 2018

\section{References}

https://dar-us-salam.com/TheNobleQuran/

Hoffman (1992) Islam the alternative, Amana publication.

An Islamic Approach to the Environment - Islam Awareness Homepage.

www.islamawareness.net/Nature/environment_approach.html Ibrahim Ozdemir, Ph.D.* ...

The Islamic View of the Environment. 3. ... If this small work assists in the growth of environmental consciousness, all humanity will profit from it.of Science, and Postmodernity), (Istanbul: Kaynak Yayinlari, 2002).( Accessed 5 Feb. 2017)

http://aboutislam.net/shariah/hadith/hadith-collections/10-green-hadiths/

www.sunni-news.net/en/articles.aspx?article_no $=28257$

25, 2013 - Below is a collection of the Prophet's hadiths that, although said 14 centuries ago, are so relevant today. The green ideas are not novel, they( visited the site 3 Feb. 2017Apr

The Full List of the 17 United Nations Sustainable Development Goals.

blog.movingworlds.org > Global Development

Aug 18, 2015 - The United Nations has published 17 Sustainable Development Goals to guide the role of public, non-profit, for-profit, and voluntary sectors in (Visited the website 1 Feb. 2017

Heaven's Lights: George Bernard Shaw and "The Genuine Islam"

heavenslights.blogspot.com/2006/04/george-bernard-shaw-and-genuine-islam.html

Apr 30, 2006 - http://www.answers.com/topic/george-bernard-shaw. Sir George Bernard Shaw in 'The Genuine Islam,' Vol. 1, No. 8, 1936. "If any religion had. 